\title{
UPAYA MENINGKATKAN HASIL BELAJAR IPS MENGGUNAKAN MODEL DIRECT INSTRUCTION DENGAN MEDIA ANIMASI PADA SDS MUHAMMADIYAH SELAT KELAS IV-A TAHUN PELAJARAN 2016/2017
}

\author{
Novi Maulana Hakim', M. Ramli ${ }^{2}$
}

\begin{abstract}
ABSTRAK
Penelitian ini bertujuan untuk (1) mendeskripsikan aktivitas belajar peserta didik dalam kegiatan belajar mengajar menggunakan Model Direct Instruction dengan Media Animasi (2) mengetahui peningkatan hasil belajar IPS Pada SDS Muhammadiyah Selat Kelas $\mathrm{IV}_{\mathrm{A}}$ setelah menggunakan Model Direct Instruction dengan Media Animasi. Jenis penelitian yang digunakan oleh peneliti adalah menggunakan rancangan penelitian tindakan kelas (PTK) yang berusaha memecahkan permasalahan yang dihadapai pada situasi sekarang. Dengan jumlah subjek penelitian 27 orang peserta didik yaitu 16 lakilaki dan 11 perempuan. Teknik analisis data secara Kualitatif dan Kuantitatif. Hasil penelitian menunjukkan bahwa: (1) Aktivitas belajar peserta didik menjadi baik pada pembelajaran IPS dengan menggunakan model Direct Instruction dengan media animasi. Siklus I aktivitas peserta didik bernilai rata-rata 3,52 dengan kategori baik dan siklus II aktivitas peserta didik bernilai rata-rata 3,94 dengan kategori baik. (2) Ada peningkatan hasil belajar setelah pembelajaran dengan menggunakan model Direct Instruction dengan media animasi pada pelajaran IPS peserta didik kelasIV A SDS Muhammadiyah Selat. Hal ini terlihat dari data hasil belajar peserta didik. Pada tes awal hasil belajar peserta didik memperoleh ketuntasan klasikal $48 \%$ dengan nilai rata-rata 61, pada siklus I hasil belajar peserta didik memperoleh ketuntasan klasikal 77\% dengan nilai rata-rata 70 dan pada siklus II hasil belajar peserta didik memperoleh ketuntasan klasikal 100\% dengan nilai rata-rata 87 mencapai KKM yang ditentukan.
\end{abstract}

(C) Universitas Muhammadiyah Palangkaraya

\section{Kata Kunci: Hasil Belajar, IPS, Model Direct Instruction, Media Animasi.}

\section{PENDAHULUAN}

Pendidikan merupakan sarana terbaik dalam mencerdaskan kehidupan bangsa, maka setiap individu yang terlibat dalam dunia pendidikan dituntut berperan secara maksimal guna meningkatkan mutu pendidikan. Tanpa pendidikan manusia tidak dapat hidup berkembang sejalan dengan cita-cita untuk maju.

Pendidikan di Kalimantan Tengah dari tahun ke tahun terus mengalami peningkatan, Karena banyak tenaga guru yang menyebar masuk ke dalam desa-desa yang tertinggal. Hal itu disebabkan oleh bantuan pemerintah yang banyak menyelenggarakan program-program ketenaga kerjaan pendidikan baik dari jenjang sekolah dasar maupun menengah atas. Dengan banyaknya lulusan diploma maupun sarjana yang berlomba-lomba mendapatkan tempat untuk memberikan pengajaran serta bimbingan kepada 
peserta didik, maka mengharuskan guru menerima semua program yang telah dibuat pemerintah dan siap ditempatkan di mana saja. Oleh karena itu, tidak ada lagi sekolah-sekolah yang kekurangan tenaga guru.

Pembelajaran ini dilakukan secara sadar dan terencana oleh guru, agar peserta didik dapat mengembangkan potensinya untuk memiliki kekuatan spiritual keagamaan, pengendalian diri, kepribadian, kecerdasan serta keterampilan yang diperlukan di masyarakat. Hal ini didukung pula dalam tujuan pendidikan yang tercantum dalam UU RI No.20 Tahun 2003, menyatakan bahwa :

Pendidikan nasional bertujuan untuk berkembangnya potensi peserta didik agar menjadi manusia yang beriman dan bertaqwa kepada Tuhan Yang Maha Esa, berakhlak mulia, sehat, berilmu, cakap, kreatif, mandiri dan menjadi warga negara yang demokrasi serta bertanggung jawab dalam rangka mencerdaskan kehidupan bangsa.

IPS (Ilmu Pengetahuan Sosial) merupakan salah satu pembelajaran yang menuntut keaktifan dari peserta didik untuk mengembangkan pemahaman dan kemampuan analisis terhadap kondisi sosial masyarakat dalam memasuki kehidupan bermasyarakat yang dinamis. Mata pelajaran IPS disusun secara sistematis, komprehensif dan terpadu dalam pembelajaran menuju kedewasaan dan keberhasilan dalam kehidupan bermasyarakat.

Menurut Susanto (2013 : 137) menyatakan bahwa "IPS adalah ilmu yang mengkaji berbagai disiplin ilmu sosial dan humaniora dan serta kegiatan dasar manusia yang dikemas secara ilmiah dalam rangka member wawasan dan pemahaman yang mendalam kepada peserta didik, khususnya ditingkat dasar dan menengah".

Materi IPS yang diajarkan di sekolah harus dipilih dan disesuaikan dengan tujuan pendidikan, penentuan materi IPS hendaknya bertujuan untuk mengembangkan kompetensi dan kepribadian peserta didik serta sesuai dengan tuntutan seiringan dengan kemajuan ilmu dan teknologi.

Untuk mencapai semua itu diperlukan dukungan dari semua pihak terutama para guru, dalam hal ini guru harus lebih aktif dan kreatif dalam mengelola kelas agar tercipta suasana pembelajaran yang menyenangkan.

Pengelolaan kelas yang baik akan melahirkan interaksi belajar mengajar yang baik. Tujuan pembelajaran pun dapat dicapai tanpa menemukan kendala yang berarti proses belajar mengajar tidak lepas dari berbagai faktor yang mempengaruhi dan menunjang keberlangsungannya. Salah satu penunjang utamanya adalah model pembelajaran yang digunakan oleh guru.

guru diharapkan tidak hanya menggunakan satu model pembelajaran saja, akan tetapi divariasikan dengan model pembelajaran yang lain agar pembelajaran menyenangkan bagi peserta didik. Salah satu model pembelajaran yang dapat digunakan oleh guru adalah model Direct Instruction atau Pembelajaran Langsung. 
Model Direct Instruction atau pembelajaran langsung adalah model pembelajaran yang menekankan pada penguasaan konsep dan perubahan perilaku dengan mengutamakan pendekatan deduktif, dengan ciri-ciri sebagai berikut:

(1) Transformasi dan ketrampilan secara langsung; (2) Pembelajaran berorientasi pada tujuan tertentu; (3) Materi pembelajaran yang telah terstuktur; (4) Lingkungan belajar yang telah terstruktur; dan

Distruktur oleh guru.

$$
\text { Guru berperan sebagai }
$$
penyampai informasi, dalam hal ini guru seyogyanya menggunakan berbagai media yang sesuai, misalnya film, tape recorder, gambar, peragaan dan sebagainya. Informasi yang disampaikan dapat berupa pengetahuan prosedural (yaitu pengetahuan tentang bagaimana melaksanakan sesuatu) atau pengetahuan deklaratif (yaitu pengetahuan tentang sesuatu dapat berupa fakta, konsep, prinsip atau generalisasi). Kritik terhadap penggunaan model pembelajaran antara lain bahwa model pembelajaran ini tidak dapat digunakan setiap waktu dan tidak untuk semua tujuan pembelajaran dan semua peserta didik.

Berdasarkan hasil observasi yang dilakukan oleh peneliti pada hari rabu tanggal 8 februari 2017, Guru lebih jarang menerapkan metode atau model

\section{METODE PENELITIAN}

Penelitian ini merupakan Penelitian Tindakan Kelas (PTK) yang dikategorikan sebagai penelitian yang berusaha untuk memecahkan atau yang bervariasi, sehingga peserta didik kurang antusias dalam mengikuti pembelajaran dan menyebabkan hasil belajar IPS rendah pada materi “Trasnsportasi”. Selain itu ada beberapa peserta didik yang takut bertanya langsung kepada guru jika ada yang belum mereka mengerti atau pahami. Apabila hal ini dibiarkan, akan berdampak pada hasil belajar mereka. Mengenai hasil belajar IPS kelas IV A $_{\text {di }}$ SDS Muhammadiyah Selat masih ada peserta didik yang memperoleh nilai kurang dari 65, dari seluruh peserta didik yang berjumlah 27 orang, ada 12 Orang (44\%) yang mendapat nilai diatas 65 dan 15 orang $(56 \%)$ yang mendapat nilai dibawah 65, sedangkan nilai KKM untuk pelajaran IPS adalah 65 .

Alasan peneliti memilih menggunakan model Direct Instruction atau Pembelajaran Langsung dalam penelitian, karena model Direct Instruction atau Pembelajaran Langsung, meminta peserta didik agar dapat memahami konsep dan merubah tingkah laku yang telah ditentukan oleh guru dalam pembelajaran.

Berdasarkan fenomena yang terjadi di atas, maka peneliti tertarik untuk melakukan penelitian dengan judul "Upaya Meningkatkan Hasil Belajar IPS Menggunakan Model Direct Instruction Dengan Media Animasi Pada SDS Muhammadiyah Selat Kelas IV A Tahun Pelajaran 2016/2017”.

menjawab permasalahan yang dihadapi oleh situasi tertentu.

Mcniff (Hamid Darmadi, 2015: 1) memandang PTK sebagai bentuk penelitian reflektif yang dilakukan oleh 
guru, perancang kurikulum, pengembang sekolah dan dilakukan untuk meningkatkan mutu, prestasi dan hasil belajar, pengembangan keahlian mengajar, penerapan model pembelajaran serta prinsip pemajuan pengembangan yang lainnya. Dengan melaksanakan PTK memungkinkan guru secara reflektif dapat menganalisis dan menyintesis hal-hal yang perlu dilakukan di dalam kelas. Dengan melaksanakan PTK guru dapat memperbaiki praktik-praktik pembelajaran sehingga memperoleh mutu, prestasi dan hasil belajar yang lebih baik. Guru tidak perlu takut terganggu kegiatannya dalam mencapai target kurikulum yang dibebankan kepadanya jika akan melaksanakan PTK.

Menurut Arikunto (Suyadi, 2012: 18) PTK adalah gabungan

\section{HASIL DAN PEMBAHASAN}

Berdasarkan analisis data yang dilakukan terhadap aktivitas peserta didik dapat diperoleh hasil aktivitas peserta didik pada setiap siklus. Saat observasi pada bulan februari 2017 bahwa aktivitas peserta didik masih kurang pada saat proses pembelajaran karena masih ditemukan peserta didik kurang berpartisipasi, kurang antusias, kurang memahami materi yang diajarkan dan hasil pembelajaran IPS masih rendah maka dari itu peneliti menerapkan judul "Upaya Meningkatkan Hasil Belajar IPS Dengan Menggunakan Model Direct Instruction Dengan Media Animasi Di SDS Muhammadiyah Selat Tahun Pelajaran 2016/2017". pengertian dari kata penelitian tindakan dan kelas. Penelitian adalah kegiatan mengamati suatu objek, dengan menggunakan kaidah metodologi tertentu untuk mendapatkan data yang bermanfaat bagi penelitian dan orang lain demi kepentingan bersama. Suatu penelitian akan menghasilkan kesimpulan yang tepat, apabila menggunakan jenis penelitian yang tepat dan benar sesuai dengan masalah yang diteliti, situasi dan kondisi saat penelitian tersebut dilakukan.

Berdasarkan pendapat para ahli diatas dapat disimpulkan bahwa penelitian tindakan kelas adalah suatu proses kegiatan pembelajaran yang dilakukan guru untuk mengamati peserta didik untuk meningkatkan hasil belajar peserta didik.

Penelitian ini dilakukan dalam dua siklus yang masing-masing siklusnya terdiri dari empat tahapan yaitu (1) Perencanaan, dalam tahap ini, peneliti menjelaskan tentang, mengapa, kapan, di mana dan bagaimana tindakan dilakukan. (2) pelaksanaan yang merupakan implementasi atau isi penerapan rancangan. (3) Pengamatan (observasi) kegiatan yang dilakukan oleh pengamat yaitu mengenai tindakan kelas. (4) Refleksi merupakan kegiatan untuk mengemukakan kembali apa yang sudah dilakukan, kegiatan refleksi ini sangat tepat dilakukan ketika guru pelaksana sudah selesai melakukan tindakan. Hasil pengamatan terhadap aktivitas guru dan peserta didik dalam 
pembelajaran IPS pada materi Transportasi oleh dua orang pengamat.

Melalui perbaikan pembelajaran dengan menggunakan model Direct Instruction dengan media animasi pada materi Transportasi yang dilaksanakan oleh peneliti di kelas $\mathrm{IV}_{\mathrm{A}}$ SDS Muhammadiyah Selat. Aktivitas guru dan peserta didik pada siklus I ada peningkatan yang baik, dengan penilaian pengamat satu dan pengamat dua memperoleh nilai rata-rata 3,55 untuk aktivitas guru, sedangkan penilaian pengamat satu dan pengamat dua memperoleh nilai rata-rata 3,52 untuk aktivitas peserta didik. Pada siklus II ada peningkatan yang baik, dengan penilaian pengamat satu dan pengamat dua memperoleh nilai ratarata 3,88 untuk aktivitas guru, sedangkan penilaian pengamat satu dan pengamat dua memperoleh nilai ratarata 3,94 untuk aktivitas peserta didik. Berdasarkan hasil tersebut dapat dilihat bahwa terjadi peningkatan aktivitas guru dan peserta didik pada siklus I dan siklus II.

Data hasil penelitian diambil dari hasil kegiatan pembelajaran IPS siklus I dan siklus II yang dilakukan di kelas IV A SDS Muhammadiyah Selat dengan jumlah peserta didik 27 orang sebagai subjek penelitian. Data hasil penelitian ini akan dipaparkan berupa data tes hasil belajar (data awal berupa nilai pre test, nilai post test pada siklus I dan siklus II).

\section{SIMPULAN}

Berdasarkan hasil penelitian yang telah dibahas sebelumnya, maka dapat disimpulkan beberapa hal, yaitu:
Hasil data awal, siklus I dan siklus II terlihat adanya peningkatan hasil belajar pada pelajaran IPS dengan materi Transportasi dengan menggunakan model Direct Instruction dengan media animasi terhadap peserta didik kelas IV $_{\text {A }}$ SDS Muhammadiyah Selat. Dapat dilihat bahwa pada data awal peserta didik hanya memperoleh rata-rata 61 sehingga nilai ini masih jauh dari kriteria ketuntasan yaitu 65 .

Hasil ketuntasan belajar peserta didik hanya memperoleh nilai sebesar $48 \%$ sehingga nilai ini masih sangat jauh dari kriteria ketuntasan klasikal, nilai yang ditentukan yaitu $85 \%$. Kemudian pada siklus I nilai rata-rata peserta didik meningkat menjadi 70 mencapai KKM yang ditentukan. Hasil ketuntasan klasikal 78\%, nilai ini masih belum kriteria ketuntasan klasikal yang ditentukan.

Pada siklus II nilai rata-rata peserta didik meningkat menjadi 87 yang mencapai KKM yang ditentukan. Hasil ketuntasan klasikal 100\%, nilai ini telah mencapai kriteria ketuntasan klasikal yang ditentukan

Berdasarkan hasil tersebut, telah terjadi peningkatan hasil belajar IPS dengan menggunakan model Direct Instruction dengan media animasi dari data awal dengan rata-rata 61 dan siklus I dengan nilai rata-rata 70 dan Siklus II dengan nilai rata-rata 87. Sehingga dapat dilihat hasil belajar meningkat dari pra siklus, siklus I dan siklus II.

Aktivitas belajar peserta didik menjadi baik pada pembelajaran IPS dengan menggunakan model Direct Instruction dengan media animasi. 
Siklus I aktivitas peserta didik bernilai rata-rata 3,52 dengan kategori baik dan siklus II aktivitas peserta didik bernilai rata-rata 3,94 dengan kategori baik.

Ada peningkatan hasil belajar setelah pembelajaran dengan menggunakan model Direct Instruction dengan media animasi pada pelajaran IPS peserta didik kelasIV A $_{\text {SDS }}$ Muhammadiyah Selat. Hal ini terlihat dari data hasil belajar peserta didik.

\section{DAFTAR PUSTAKA}

Darmadi, Hamid. (2015). Desain dan Implementasi Penelitian Tindakan Kelas (PTK). Bandung : Alfabeta.
Pada tes awal hasil belajar peserta didik memperoleh ketuntasan klasikal 48\% dengan nilai rata-rata 61 , pada siklus I hasil belajar peserta didik memperoleh ketuntasan klasikal $77 \%$ dengan nilai rata-rata 70 dan pada siklus II hasil belajar peserta didik memperoleh ketuntasan klasikal 100\% dengan nilai rata-rata 87 mencapai KKM yang ditentukan.

Suyadi. (2012). Buku Panduan Guru Penelitian Tindakan Kelas. Yogyakarta. Andi. 